\title{
Epidemiology of Taenia saginata taeniosis/cysticercosis: a systematic review of the distribution in West and Central Africa
}

\author{
Emilie Hendrickx ${ }^{1}$, Lian F. Thomas ${ }^{2,3}$, Pierre Dorny ${ }^{1,4}$, Branko Bobić ${ }^{5}$, Uffe Christian Braae ${ }^{6,7}$, \\ Brecht Devleesschauwer ${ }^{8,9}$, Ramon M. Eichenberger ${ }^{10}$, Sarah Gabriël ${ }^{8}$, Anastasios Saratsis ${ }^{11}$, Paul R. Torgerson ${ }^{10}$, \\ Lucy J. Robertson ${ }^{12}$ and Veronique Dermauw ${ }^{1 *}$ (D)
}

\begin{abstract}
Background: The zoonotic tapeworm Taenia saginata, although causing only minor discomfort in humans, is responsible for considerable economic losses in the livestock sector due to condemnation or downgrading of infected beef carcasses. An overview of current knowledge on the distribution and prevalence of this parasite in West and Central Africa is lacking.

Methods: We conducted a systematic review, collecting information on published and grey literature about T. saginata taeniosis and bovine cysticercosis from 27 countries/territories in West and Central Africa, published between January 1st, 1990 and December 31st, 2017.

Results: The literature search retrieved 1672 records, of which 51 and 45 were retained for a qualitative and quantitative synthesis, respectively. Non-specified human taeniosis cases were described for Nigeria, Cameroon, Senegal, Burkina Faso, Democratic Republic Congo, Guinea, and Ivory Coast (seven out of 27 countries/territories), while T. saginata taeniosis specifically was only reported for Cameroon. Most prevalence estimates for taeniosis ranged between 0-11\%, while three studies from Nigeria reported prevalence estimates ranging between $23-50 \%$. None of the studies included molecular confirmation of the causative species. The presence of bovine cysticercosis was reported for Benin, Burkina Faso, Cameroon, Central African Republic, Chad, Democratic Republic Congo, Ghana, Guinea, Ivory Coast, Mali, Niger, Nigeria, Senegal, and Tristan da Cunha (14 out of 27 countries/territories). Prevalence estimates ranged between 0-29\%.
\end{abstract}

Conclusions: Our systematic review has revealed that human taeniosis and bovine cysticercosis are seriously understudied in West and Central Africa. The high prevalence estimates of both conditions suggest an active dissemination of this parasite in the region, calling for a concerted One Health action from public health, veterinary health and food surveillance sectors.

Keywords: Taenia saginata, Cysticercosis, Cattle, Beef, Tapeworm, West Africa, Central Africa

\footnotetext{
*Correspondence: vdermauw@itg.be

${ }^{1}$ Department of Biomedical Sciences, Institute of Tropical Medicine,

Antwerp, Belgium

Full list of author information is available at the end of the article
} 


\section{Background}

The tapeworm Taenia saginata is one of three Taenia species that infect humans as their definitive host, with bovines serving as the intermediate host. Humans acquire T. saginata infection after consuming undercooked beef containing viable cysticerci. The adult tapeworm resides in the small intestine, where it becomes patent within approximately ten weeks. At that moment, the strobila may have reached a length of up to three meters [1], and gravid proglottids can contain up to 100,000 taeniid eggs. These eggs are voided during and between defecation [2], and have the potential to survive for a long time without hatching. Eggs found in faecal material and eggs within soil have been documented to remain viable for up to 9.5 months [3]. Contaminated pastures, water and feed are a source of infection for cattle. Following ingestion, the early larval stages (oncospheres) hatch and the hexacanth larvae migrate, utilising the lymphatic and blood system, to the muscle tissue. Here the larvae mature into the metacestode stage, called cysticerci [4].

Unlike Taenia solium, for which humans can also act as a dead-end intermediate host leading to the debilitating and stigmatising disease neurocysticercosis, human $T$. saginata infections are restricted to the definitive (adult tapeworm) stage, which has a more limited public health burden. Taenia saginata taeniosis is generally asymptomatic or associated with mild abdominal discomfort, although more serious complications, including appendicitis, intestinal obstruction and gall bladder perforation have occasionally been documented [3]. Bovine cysticercosis, however, may result in substantial economic losses generated for the food industry because of meat condemnation, treatment processing costs and an overall reduction in the product value [5]. Moreover, the meat inspection process itself requires substantial (veterinary) public health sector investment and there are costs associated with treatment seeking behaviour, diagnostics, and treatment of human taeniosis cases [5, 6].

Taenia saginata is considered to have a global distribution, with higher prevalences in low-income regions where sanitation standards may be poor, and the meat inspectorate services are often poorly funded and understaffed.

In West and Central Africa, the cattle population amounts to 120 million heads [7]. While West Africa mainly consists of arid (and to lesser degree semi-arid and sub-humid) agro-ecological zones, Central Africa predominantly consists of humid zones (with some sub-humid zones as well) [8]. In the purely humid agroecological zones, cattle production is not considered an important economic activity due to the presence of diseases such as trypanosomiasis [8]. In the arid zones, pastoralism is the most commonly cattle production system, while the semi-arid and sub-humid zones in the area are characterized by mixed crop-livestock farming systems [8].

As a summary of existing knowledge on the occurrence of $T$. saginata taeniosis and bovine cysticercosis in the area is presently lacking, and as part of a coordinated effort to document the global distribution of T. saginata [9-14], we undertook a systematic review of the occurrence of this parasite in West and Central Africa.

\section{Methods \\ Search strategy}

We conducted a systematic review aiming to gather current knowledge on the occurrence, prevalence and geographical distribution of human taeniosis and bovine cysticercosis in West and Central Africa, published between January 1st, 1990 and December 31st, 2017. A complete study protocol is available in Additional file 1: Text S1. In the context of this study, West and Central Africa was defined as the area covering the following 27 countries/territories: Ascension, Benin, Burkina Faso, Cameroon, Cape Verde, Central African Republic, Chad, Republic of the Congo, Democratic Republic of the Congo (DR Congo), Equatorial Guinea, Gabon, The Gambia, Ghana, Guinea, Guinea-Bissau, Ivory Coast, Liberia, Mali, Mauritania, Niger, Nigeria, Saint Helena, Sao Tome and Principe, Senegal, Sierra Leone, Togo and Tristan da Cunha. Although Angola is classified as being part of Central Africa, it is also classified as being part of southern Africa, and data from this country were included in an equivalent systematic review of southern and eastern Africa [14].

The international scientific databases Web of Science (http://ipscience.thomsonreuters.com/product/web-ofscience/) and PubMed (http://www.ncbi.nlm.nih.gov/ pubmed) were searched using the following combination of key words: (cysticerc* OR cisticerc* OR "C. bovis" OR taenia* OR tenia* OR saginata OR taeniosis OR teniosis OR taeniasis OR ténia OR taeniid OR cysticerque) AND (Ascension OR Benin OR "Burkina Faso" OR Cameroon OR "Cape Verde" OR "Central African Republic" OR Chad OR Congo-Brazzaville OR DRC OR Congo OR "Cote d'Ivoire" OR "Equatorial Guinea" OR Gabon OR Gambia OR Ghana OR Guinea OR Guinée OR Guinea-Bissau OR Liberia OR Mali OR Mauritania OR Niger OR Nigeria OR "Saint Helena" OR Sao Tome OR Principe OR Senegal OR "Sierra Leone" OR Togo OR "Tristan da Cunha"). Moreover, databases for MSc/PhD theses and grey literature (Additional file 2: Text S2) were searched using the same search phrase. Furthermore, the OIE databases "Help with World Animal Disease Status" ("Handistatus", 1996-2004) [15] and "World Animal Health Information System" (“WAHIS", 2005) [16] were 
consulted to extract data on bovine cysticercosis for the study area. Finally, reference lists of relevant reviews were screened for additional records.

\section{Selection criteria}

The PRISMA guidelines were followed for reporting the review (Additional file 3: Table S1). Briefly, duplicate records were removed after compiling results from the different searches, followed by screening of titles and abstracts for relevance. Then, full text articles were evaluated using the following exclusion criteria: (i) studies concerning a parasite different from $T$. saginata; (ii) studies conducted outside the study area; (iii) studies published outside the study period; (iv) studies reporting results outside the scope of our review question (e.g. review, experiment, intervention); and (v) duplicated data. No language restrictions were implemented.

\section{Data extraction and compilation}

Data from included records were extracted. Where records reported both the numerator and denominator of the study sample, respectively, prevalence and 95\% Wilson score confidence intervals (CI) were calculated. All calculations were conducted in $\mathrm{R}$, version 3.5.2.

\section{Results}

\section{Search results}

In total, 1670 records were retrieved, including 1655 through database searching, while 17 additional records were identified, including 15 retrieved through reference list screening, and the OIE databases Handistatus [15] and WAHIS [16]. After the removal of duplicates, out of 1237 remaining records, 1235 underwent title and abstract screening (i.e. the abstract was unavailable for 2 records). Subsequently, full texts of 87 articles were assessed for eligibility, of which 51 articles were retained for the qualitative synthesis (45 journal articles, 3 conference abstracts, 2 databases, 1 letter to the editor), of which 45 were included in the quantitative synthesis (Additional file 4: Figure S1).

\section{Human taeniosis}

A total of 45 records described human taeniosis cases, of which 39 were included in the quantitative synthesis (Table 1). Out of 45 records, 35 describe results from Nigeria, 3 from Cameroon, 3 from Senegal, 1 from Burkina Faso, 1 from DR Congo, 1 from Guinea and 1 from Ivory Coast (Fig. 1). No data were available for the other countries in the study area.

All studies included in the quantitative synthesis used plain stool microscopy as a diagnostic tool, and prevalence estimates for taeniosis ranged between $0-11 \%(0 \%$ in suburban schoolchildren [17] and $11 \%$ in community residents [18] both in Nigeria). Three other studies performed in Nigeria; however, they reported much higher prevalence estimates: $23 \%$ in primary schoolchildren [19], 33\% in rural schoolchildren [17] and even 50\% in pre-school-age children (aged between 0 and 71 months) [20]. In four other studies, excluded from the quantitative synthesis, the presence of T. saginata taeniosis was described for Nigeria, Ivory Coast and Senegal, without prevalence estimates [21-24]. A further two case reports were also excluded from the qualitative synthesis: the first case described the presence of Meckel's diverticulitis due to T. saginata taeniosis in a 6-year-old girl in Nigeria [25], and the other a case of T. saginata taeniosis in a 33-year-old male presumably infected in Ivory Coast but diagnosed in Spain [26]. Only five studies reported the specific presence of $T$. saginata taeniosis; none of the studies mentioned morphological identification or molecular confirmation of the causative species, although one study conducted in Cameroon mentioned that species identification was done based on the expelled worm.

\section{Bovine cysticercosis}

Only 4 journal articles in addition to the 2 OIE databases described the presence of bovine cysticercosis in the study area, 3 of which were included in the quantitative synthesis (Table 2$)$. The journal articles (1 described data for DR Congo, 3 for Nigeria) reported prevalence estimates based on abattoir surveys (i.e. meat inspection) between $0-29.0 \%$ (0\% [27], 29\% [28], both in Nigeria). One article, which was excluded from the quantitative synthesis, described the presence of bovine cysticercosis in Nigeria, without prevalence estimates [23].

In contrast with the journal articles, the OIE databases reported the (past) presence of bovine cysticercosis in a larger part of the study area (Table 3). Overall, bovine cysticercosis was reported throughout the study area, except for Guinea-Bissau, Sao Tomé and Principe, and Togo, where it was declared to be absent $[15,16]$ (Fig. 2). No data were available for Ascension, Cape Verde, the Republic of Congo, Equatorial Guinea, Gabon, Gambia, Liberia, Mauritania, Saint Helena or Sierra Leone.

\section{Discussion}

Our aim was to gather current knowledge on human taeniosis and bovine cysticercosis in West and Central Africa. Overall, human taeniosis was reported in seven out of 27 countries/territories, while bovine cysticercosis was reported in 14 out of 27 countries/territories. This systematic review has revealed that human $T$. saginata taeniosis and bovine cysticercosis are seriously understudied in this region. While the study area consists of 27 countries and territories, the presence of human taeniosis and bovine cysticercosis were only described for 7 
Table 1 Reported occurrence of taeniosis in West and Central Africa

\begin{tabular}{|c|c|c|c|c|c|c|c|c|}
\hline Country & Study period & $n$ & $n+$ & $\%$ & $95 \% \mathrm{Cl}$ & Species & Groups studied & Reference \\
\hline Burkina Faso & na & 1587 & na & 2.1 & na & $N$ & Community volunteers & [39] \\
\hline Cameroon & 08/1999-04/2000 & 3109 & 1 & 0.03 & $0.006-0.18$ & $Y^{a}$ & Community volunteers & {$[35]$} \\
\hline Cameroon & 03/2012-07/2012 & 396 & na & 0.25 & na & N & Patients consulting hospital & {$[40]$} \\
\hline Cameroon & na & 163 & 2 & 1.2 & $0.3-4.4$ & N & Pre-school-age children & {$[41]$} \\
\hline DR Congo & 03/04/2014-07/06/2018 & 602 & 40 & 6.6 & $4.9-8.9$ & $Y^{b}$ & School children (6-20 years) & {$[42]$} \\
\hline Guinea & 04/1995-06/1995 & 800 & na & 3.8 & na & N & Children (10-14 years) & {$[43]$} \\
\hline Nigeria & 01/02/1997-31/01/1998 & 816 & 8 & 1.0 & $0.50-1.9$ & N & Pregnant women & {$[44]$} \\
\hline Nigeria & 07/02/1998-31/12/1998 & 129 & 3 & 2.3 & $0.8-6.6$ & $Y^{b}$ & $\begin{array}{l}\text { Patients with complaints of upper abdominal pain, tenderness } \\
\text { and indigestion }\end{array}$ & {$[45]$} \\
\hline Nigeria & 03/2000-09/2000 & 500 & 16 & 3.2 & $2.0-5.1$ & $\mathrm{~N}$ & Schoolchildren & {$[46]$} \\
\hline Nigeria & $1 / 11 / 2003-30 / 1 / 2004$ & 60 & 2 & 3.3 & $0.9-11.4$ & $Y^{b}$ & Children ( $2-6$ years) attending clinic & {$[47]$} \\
\hline Nigeria & $11 / 2004-02 / 2005$ & 232 & 23 & 9.9 & $6.7-14.4$ & $\mathrm{~N}$ & Primary schoolchildren & {$[48]$} \\
\hline Nigeria & $01 / 2005-05 / 2005$ & 309 & 5 & 1.6 & {$[0.7 ; 3.7]$} & $\mathrm{N}$ & Schoolchildren & [49] \\
\hline Nigeria & $06 / 2005-11 / 2006$ & 1059 & 102 & 9.6 & $8.0-11.6$ & $\mathrm{~N}$ & Schoolchildren & {$[50]$} \\
\hline Nigeria & $10 / 2005-03 / 2006$ & 119 & 1 & 0.8 & $0.2-4.6$ & $\mathrm{~N}$ & Outpatients health institutions & {$[51]$} \\
\hline Nigeria & 1/2006-09/2006 & 73 & 24 & 32.9 & $23.2-44.3$ & N & Rural schoolchildren & {$[17]$} \\
\hline Nigeria & $1 / 2006-09 / 2006$ & 171 & 19 & 11.1 & $7.2-16.7$ & N & Suburban schoolchildren & {$[17]$} \\
\hline Nigeria & 01/2006-09/2006 & 283 & na & 23.0 & na & $\mathrm{N}$ & Primary schoolchildren & [19] \\
\hline Nigeria & 06/2006-11/2006 & 818 & 4 & 0.5 & $0.2-1.3$ & $\mathrm{~N}$ & Hospital patients & {$[52]$} \\
\hline Nigeria & 01/2007-03/2007 & 250 & 1 & 0.4 & $0.07-2.2$ & $\mathrm{~N}$ & Schoolchildren & {$[53]$} \\
\hline Nigeria & 07/2007-08/2007 & 100 & 13 & 13.0 & $7.8-21.0$ & $\mathrm{~N}$ & $\begin{array}{l}\text { Sampling in hostels (faeces sampling in toilets, not from } \\
\text { individual participants) }\end{array}$ & {$[54]$} \\
\hline Nigeria & 08/2007-08/2009 & 500 & 0 & 0 & $0-0.8$ & N & $\begin{array}{l}\text { HIV-negative enrolled via HIV outreach programme (in houses } \\
\text { and offices) }\end{array}$ & {$[18]$} \\
\hline Nigeria & 08/2007-08/2009 & 2000 & 4 & 0.2 & $0.08-0.5$ & $\mathrm{~N}$ & HIV-positive patients attending clinic & {$[18]$} \\
\hline Nigeria & 01/2008-08/2008 & 50 & 4 & 8 & $3.2-18.8$ & $\mathrm{~N}$ & Villagers & {$[32]$} \\
\hline Nigeria & 05/2009-07/2009 & 122 & 2 & 1.6 & $0.5-5.8$ & $\mathrm{~N}$ & Abattoir workers & {$[55]$} \\
\hline Nigeria & 05/2009-07/2009 & 98 & na & 0 & na & $\mathrm{N}$ & Control populations & {$[55]$} \\
\hline Nigeria & $08 / 2010-12 / 2010$ & 600 & 19 & 3.2 & $2.0-4.9$ & $\mathrm{~N}$ & Schoolchildren & {$[56]$} \\
\hline Nigeria & $01 / 2011-12 / 2011$ & 3826 & na & 0.89 & na & $\mathrm{N}$ & Primary schoolchildren & [57] \\
\hline Nigeria & 06/2011-11/2011 & 220 & na & 5 & na & $N$ & Schoolchildren aged $1-15$ years & {$[58]$} \\
\hline Nigeria & $06 / 2012-12 / 2012$ & 116 & 10 & 8.6 & $4.7-15.1$ & $Y^{b}$ & Food vendors & {$[59]$} \\
\hline Nigeria & 09/2012-01/2013 & 717 & 5 & 0.7 & $0.3-1.6$ & $\mathrm{~N}$ & Samples from polio surveillance programme & {$[60]$} \\
\hline Nigeria & 02/2014-06/2014 & 167 & 84 & 50.3 & $42.8-57.8$ & $\mathrm{~N}$ & Pre-school-age children & {$[20]$} \\
\hline Nigeria & $07 / 2014-11 / 2014$ & 112 & 3 & 2.7 & $0.9-7.6$ & $\mathrm{~N}$ & Community volunteers & {$[61]$} \\
\hline Nigeria & na & 750 & 16 & 2.1 & $1.3-3.4$ & N & Women (child up to senior) & {$[62]$} \\
\hline Nigeria & na & 471 & 1 & 0.2 & $0.04-1.2$ & $\mathrm{~N}$ & Primary schoolchildren & {$[63]$} \\
\hline Nigeria & na & 96 & 1 & 1 & $0.2-5.7$ & $\mathrm{~N}$ & HIV patients & {$[64]$} \\
\hline Nigeria & na & 168 & 8 & 4.8 & $2.4-9.1$ & N & Food vendors & {$[65]$} \\
\hline Nigeria & na & 296 & 11 & 3.7 & $2.1-6.5$ & N & Villagers & {$[66]$} \\
\hline Nigeria & na & 162 & 2 & 1.2 & $0.3-4.4$ & $\mathrm{~N}$ & Primary schoolchildren & {$[67]$} \\
\hline Nigeria & na & 400 & 12 & 3.0 & $1.7-5.2$ & N & Primary schoolchildren & {$[68]$} \\
\hline Nigeria & na & 416 & 45 & 10.8 & $8.2-14.2$ & N & Nursery and primary school children & {$[69]$} \\
\hline Senegal & 04/1997 & 400 & na & 3.5 & na & N & Schoolchildren & {$[70]$} \\
\hline Senegal & 2004 & na & na & 4.6 & na & N & Routine analyses at parasitology laboratory & {$[71]$} \\
\hline Senegal & 2005 & na & na & 5.6 & na & N & Routine analyses at parasitology laboratory & {$[71]$} \\
\hline Senegal & 2006 & na & na & 4.0 & na & N & Routine analyses at parasitology laboratory & {$[71]$} \\
\hline Senegal & 2007 & na & na & 7.0 & na & N & Routine analyses at parasitology laboratory & [71] \\
\hline Senegal & 2008 & na & na & 5.5 & na & $\mathrm{N}$ & Routine analyses at parasitology laboratory & {$[71]$} \\
\hline Senegal & 2009 & na & na & 4.1 & na & $\mathrm{N}$ & Routine analyses at parasitology laboratory & {$[71]$} \\
\hline
\end{tabular}

a Species identification based on expelled worm

b Reported as Taenia saginata, yet unclear from methodology how species identification was done

Abbreviations: $n$, number of individuals tested; $n+$, number of positive individuals; $\mathrm{Cl}$, confidence interval; na, not available; $\mathrm{Y}$, yes; $\mathrm{N}$, no 


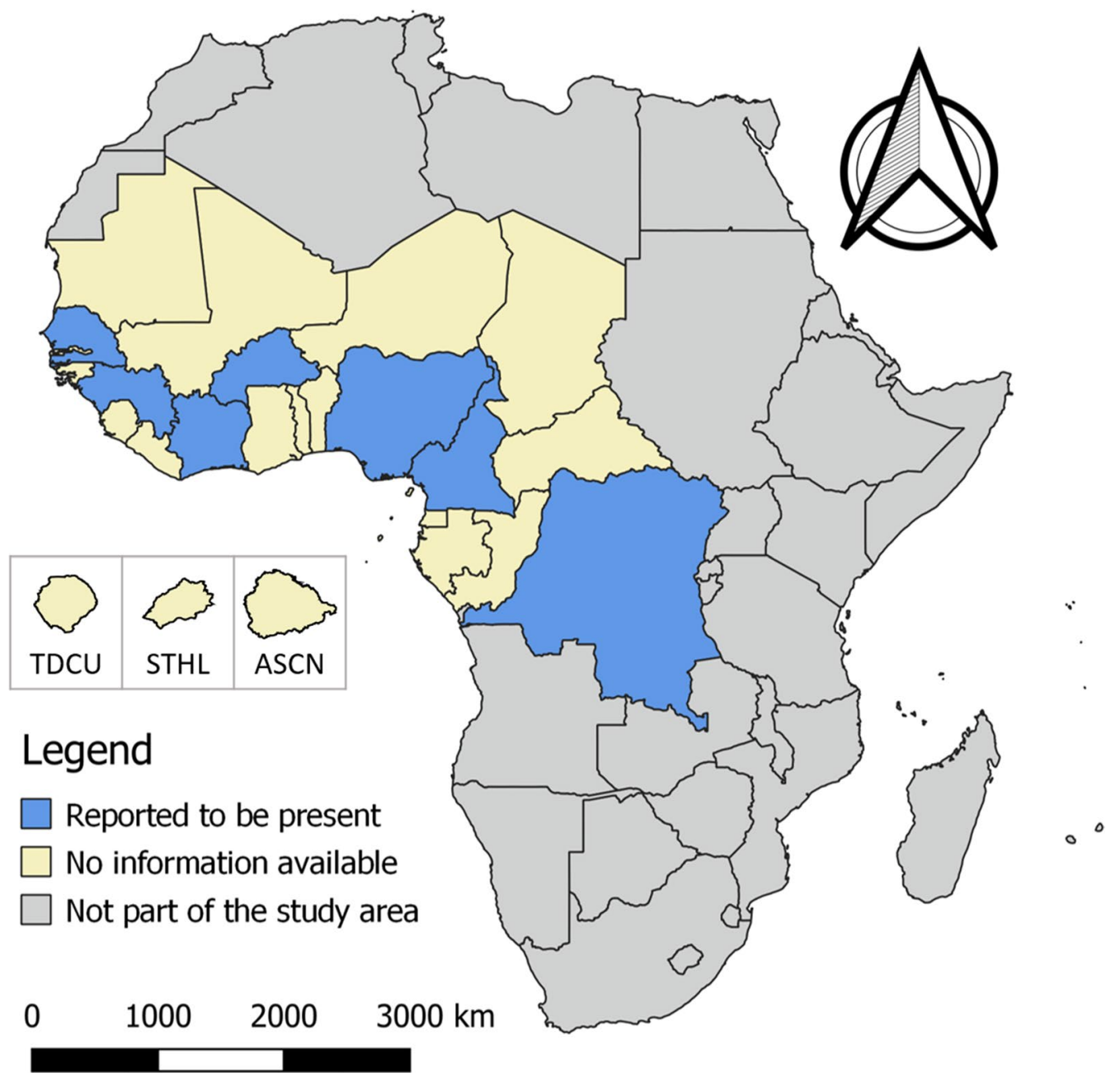

Fig. 1 Human taeniosis in West and Central Africa. The islands Tristan da Cunha (TDCA), Saint Helena (STHL) and Ascension (ASCN) are magnified (i.e. they are not shown according to the given scale) to improve presentation

and 17 countries, respectively. For the remaining regions no data were reported. These findings are in contrast to eastern and southern Africa which have similar lifestyles yet a remarkably higher coverage [12]. This difference might be partially explained by the presence of a large French speaking population in West and Central Africa, and therefore potentially published research in journals which were not detected completely by our search strategy, although we had included French search terms and some articles in French were included in the present study. Another explanation might be a lower awareness and interest in the topic, as the cattle population in this area is somewhat lower as compared to eastern and southern Africa, i.e. 120 million heads [7] as opposed to 184 million heads [7].

Overall, the reported prevalence estimates of taeniosis were in line with those reported in eastern and southern Africa [12] and in the Americas [13], but higher than those reported in western and eastern Europe $[9,10]$. In contrast to certain areas in eastern and southern Africa where consumption of raw beef is a culinary habit [12], traditional dishes in West and Central Africa include mainly stews with typically extended cooking times [29, 30], thereby decreasing the risk of exposure to viable $T$. saginata cysts. Three articles, however, reported very high taeniosis prevalence estimates, with $23 \%$ in primary schoolchildren [19], 33\% in rural schoolchildren [17] and even $50 \%$ in pre-school-age children [20]. According to Adeniran et al. [20], Nigerian pre-school-age children are often fed undercooked meals for adults, including beef, in order to facilitate the transition from breastmilk to solid food. Should this high prevalence estimate be confirmed, such practices should be investigated and be the subject of close attention and education on the potential dangers associated with consumption of inadequately cooked food. In all taeniosis cases, species identification 
Table 2 Reported occurrence of bovine cysticercosis in West and Central Africa: reports based on meat inspection

\begin{tabular}{llllllll}
\hline Country & Study period & Data source & $n$ & $n+$ & $\%$ & $95 \% \mathrm{Cl}$ & Reference \\
\hline Congo & $06 / 1986-06 / 1987$ & Veterinary inspection records & 3914 & na & 9.6 & na & [72] \\
Congo & $07 / 1986-10 / 1988$ & Veterinary inspection records & 333 & na & 10.5 & na & {$[72]$} \\
Congo & $07 / 1986-10 / 1988$ & Veterinary inspection records & 284 & na & 12.7 & na & {$[72]$} \\
Congo & na & Veterinary inspection records & 73 & na & 1.4 & na & {$[72]$} \\
Congo & na & Veterinary inspection records & 47 & na & 4.3 & na & {$[72]$} \\
Congo & na & Veterinary inspection records & 35 & na & 14.3 & na & {$[72]$} \\
Nigeria & $1985-1986$ & Veterinary inspection records & 1221 & 0 & 0 & $0-0.3$ & {$[27]$} \\
Nigeria & $1985-1986$ & Retail market inspection by investigators & 358 & 27 & 7.5 & $5.2-10.8$ & {$[27]$} \\
Nigeria & $11 / 1999-04 / 2002$ & Carcass inspection by investigators & 5560 & 1,610 & 29.0 & $27.8-30.2$ & {$[28]^{\text {a }}$} \\
Nigeria & $11 / 1999-04 / 2002$ & Carcass inspection by investigators & 20,240 & 5,140 & 25.4 & $24.8-26.0$ & {$[28]^{b}$} \\
Nigeria & 2005-2007 & Veterinary inspection records & 641,224 & 805 & 0.13 & $0.12-0.13$ & {$[73]$} \\
\hline
\end{tabular}

a Local breeds in rural areas

b Exotic breeds in urban areas

Abbreviations: $n$, number of individuals tested; $n+$, number of positive individuals; $\mathrm{Cl}$, confidence interval; na, not available

Table 3 OlE data on occurrence of bovine cysticercosis in West and Central Africa (1996-2005) [15, 16]

\begin{tabular}{|c|c|c|c|c|c|c|c|c|c|c|}
\hline Country/territory & 1996 & 1997 & 1998 & 1999 & 2000 & 2001 & 2002 & 2003 & 2004 & 2005 \\
\hline \multicolumn{11}{|l|}{ Ascension } \\
\hline Benin & & & & & & & & + & 79 & \\
\hline Burkina Faso & + & + & + & & & & & & & + \\
\hline Cameroon & & + & + & + & + & + & + & 21 & 23 & + \\
\hline \multicolumn{11}{|l|}{ Cape Verde } \\
\hline Central African Republic & + & & & & & + & + & & + & + \\
\hline Chad & & & & & & & + & & & \\
\hline DR Congo & & & & & & & + & & & + \\
\hline \multicolumn{11}{|l|}{ Republic of the Congo } \\
\hline \multicolumn{11}{|l|}{ Equatorial Guinea } \\
\hline \multicolumn{11}{|l|}{ Gabon } \\
\hline \multicolumn{11}{|l|}{ Gambia } \\
\hline Ghana & & + & & & & & & & & - \\
\hline Guinea & + & & & & & & & & & \\
\hline Guinea-Bissau & & & & & & & - & - & - & \\
\hline Ivory Coast & + & + & + & + & + & + & + & + & + & \\
\hline \multicolumn{11}{|l|}{ Liberia } \\
\hline Mali & + & & & & & & & & & - \\
\hline \multicolumn{11}{|l|}{ Mauritania } \\
\hline Niger & + & + & & & & + & & & & \\
\hline Nigeria & & & & + & & + & + & 153 & 34 & - \\
\hline \multicolumn{11}{|l|}{ Saint Helena } \\
\hline Sao Tome and Principe & & & & & - & - & - & - & - & \\
\hline Senegal & 92 & + & 199 & 125 & + & + & & & & \\
\hline \multicolumn{11}{|l|}{ Sierra Leone } \\
\hline Togo & & & & & & & & & & - \\
\hline Tristan da Cunha & & 71 & & & 1 & + & & 1 & & \\
\hline
\end{tabular}

Blank cells indicate the data were unavailable

Abbreviations: $\mathrm{Cl}$, confidence interval; +, occurrence of the disease; -, absence of the disease 


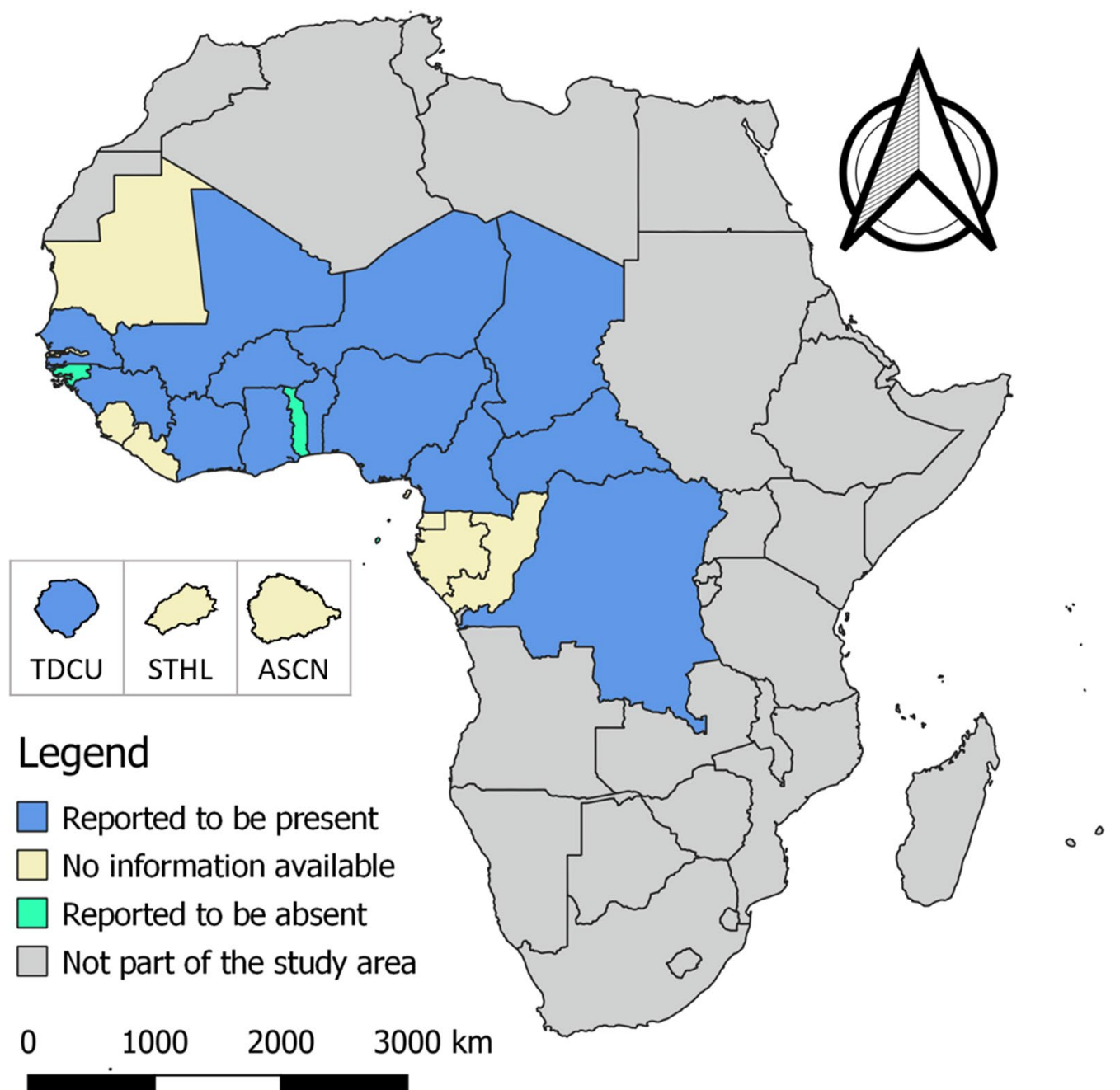

Fig. 2 Bovine cysticercosis in West and Central Africa. The islands Tristan da Cunha (TDCA), Saint Helena (STHL) and Ascension (ASCN) are magnified (i.e. they are not shown according to the given scale) to improve presentation

is pivotal to avoid the potential ingestion of T. solium eggs by the tapeworm carrier, and relatives and acquaintances, representing a risk of neurocysticercosis. Taenia solium is endemic in many of the included countries or territories [31-36]. Most studies, however, reported nonspecified taeniosis, and for those specifically mentioning $T$. saginata taeniosis only one described the applied method. None of the other studies reported the use of specific morphological methods or molecular tools allowing for the identification of the causative Taenia sp. [9]. Hence, we cannot rule out that a certain proportion of taeniosis cases summarized in this review are due to $T$. solium instead of $T$. saginata.

A wide fluctuation in prevalence estimates, ranging between $10-30 \%$ for most studies [37] was observed for bovine cysticercosis, which is comparable to the estimates for eastern and southern Africa [12]. In many countries, meat inspection is not done systematically, especially in the case of backyard slaughtering in rural areas where meat inspection may not be available. Moreover, a correct estimation of the prevalence through meat inspection is hampered by its low sensitivity, which is estimated to lie below 16\% [38]. This was confirmed by one study from Nigeria describing the prevalence of bovine cysticercosis in carcasses having passed the regular meat inspection at the abattoir. While the regular veterinary inspection declared the carcasses to be free from cysticercosis, investigators found a prevalence of $7.5 \%$ in carcasses originating from the same abattoir, sold at retail markets [27]. Overall, prevalence estimates for taeniosis of up to $50 \%$, and for bovine cysticercosis of up to $30 \%$, indicate the continued transmission of this parasite between cattle and humans. Despite the limited pathology caused by $T$. saginata, bovine cysticercosis has the 
potential to cause a high economic cost due to condemnation of infected carcasses. To interrupt transmission, stringent meat inspection procedures should be applied and improvements implemented in the sanitation and management of human sewage. The public should also be educated regarding general food safety measures such as thorough cooking of meat products, which also reduces the risk of infection with other microbiological hazards associated with meat products, such as pathogenic Escherichia coli, Salmonella spp., Mycobacterium bovis and Campylobacter spp.

\section{Conclusions}

Based on the findings of our systematic review, both human taeniosis and bovine cysticercosis are understudied in West and Central Africa. Included articles reported high prevalence estimates for both conditions, pointing to a continued transmission of T. saginata in the region. A One Health approach is needed to protect the general public from acquiring tapeworm infection.

\section{Additional files}

Additional file 1: Text S1. Search protocol.

Additional file 2: Text S2. Databases used.

Additional file 3: Table S1. PRISMA checklist.

Additional file 4: Figure S1. PRISMA flow diagram.

\section{Abbreviations}

Cl: confidence interval; DR Congo: Democratic Republic of the Congo; OIE: World Organisation for Animal Health/Office International des Epizooties; PRISMA: Preferred Reporting Items for Systematic Reviews and Meta-Analyses; WAHIS: World Animal Health Information System.

\section{Acknowledgements}

This work was performed within the framework of CYSTINET, the European network on taeniosis/cysticercosis, COST ACTION TD1302.

\section{Authors' contributions}

EH and VD conducted the systematic review of literature, extracted and analysed the data, and drafted the first version of the manuscript. All authors contributed to the design of the study, interpretation of the data and writing of the paper. All authors read and approved the final manuscript.

\section{Funding}

Not applicable.

\section{Availability of data and materials}

All references found eligible in our literature review are included in the article.

\section{Ethics approval and consent to participate}

Not applicable.

\section{Consent for publication \\ Not applicable.}

\section{Competing interests}

The authors declare that they have no competing interests.

\section{Author details}

${ }^{1}$ Department of Biomedical Sciences, Institute of Tropical Medicine, Antwerp, Belgium. ${ }^{2}$ International Livestock Research Institute (ILRI), P.O. Box 30709, Nairobi, Kenya. ${ }^{3}$ Institute for Infection \& Global Health, University of Liverpool, Neston, UK. ${ }^{4}$ Department of Virology, Parasitology and Immunology, Faculty of Veterinary Medicine, Ghent University, Merelbeke, Belgium. ${ }^{5}$ Centre of Excellence for Food and Vector-borne Zoonoses, Institute for Medical Research, University of Belgrade, Dr Subotića 4, Belgrade 11000, Serbia. ${ }^{6}$ One Health Center for Zoonoses and Tropical Veterinary Medicine, Ross University School of Veterinary Medicine, P.O. Box 334, Basseterre, Saint Kitts and Nevis. ${ }^{7}$ Department of Infectious Disease Epidemiology and Prevention, Statens Serum Institut, 2300 Copenhagen, Denmark. ${ }^{8}$ Department of Veterinary Public Health and Food Safety, Faculty of Veterinary Medicine, Ghent University, Merelbeke, Belgium. ${ }^{9}$ Department of Epidemiology and Public Health, Sciensano, Brussels, Belgium. ${ }^{10}$ Institute of Parasitology, Vetsuisse Faculty, University of Zurich, Zurich, Switzerland. ${ }^{11}$ Veterinary Research Institute, Hellenic Agricultural Organisation Demeter, Thermi 57001, Greece. ${ }^{12}$ Department of Food Safety and Infection Biology, Faculty of Veterinary Medicine, Norwegian University of Life Sciences, Oslo, Norway.

Received: 8 April 2019 Accepted: 24 June 2019

Published online: 27 June 2019

\section{References}

1. Craig P, Ito A. Intestinal cestodes. Curr Opin Infect Dis. 2007;20:524-32.

2. Tembo A, Craig PS. Taenia saginata taeniosis: copro-antigen time-course in a voluntary self-infection. J Helminthol. 2015;89:612-9.

3. Gonzalez A, Thomas L. Taenia spp. In: Rose JB, Jiménez-Cisneros B, editors. Global Water Pathogen Project. 2018. http://www.waterpathogens.org. Accessed 21 Jun 2019.

4. Symeonidou I, Arsenopoulos K, Tzilves D, Soba B, Gabriël S, Papadopoulos E. Human taeniasis/cysticercosis: a potentially emerging parasitic disease in Europe. Ann Gastroenterol. 2018;31:406-12.

5. Blagojevic B, Robertson LJ, Vieira-Pinto M, Vang Johansen M, LaranjoGonzález M, Gabriël S. Bovine cysticercosis in the European Union: impact and current regulations, and an approach towards risk-based control. Food Control. 2017;78:64-71.

6. Jansen F, Dorny P, Trevisan C, Dermauw V, Laranjo-González M, Allepuz A, et al. Economic impact of bovine cysticercosis and taeniosis caused by Taenia saginata in Belgium. Parasit Vectors. 2018;11:241.

7. Food and Agriculture Organization of the United Nations statistical databases. Rome: FAO; 2019. http://faostat3.fao.org. Accessed 21 Jun 2019.

8. Otte M, Chilonda P. Cattle and small ruminant production systems in sub-Saharan Africa - a systematic review. Rome: Food and Agriculture Organization of the United Nations; 2002.

9. Laranjo-González M, Devleesschauwer B, Trevisan C, Allepuz A, Sotiraki S, Abraham A, et al. Epidemiology of taeniosis/cysticercosis in Europe, a systematic review: western Europe. Parasit Vectors. 2017;10:349.

10. Trevisan C, Sotiraki S, Laranjo-González M, Dermauw V, Wang Z, Kärssin A, et al. Epidemiology of taeniosis/cysticercosis in Europe, a systematic review: eastern Europe. Parasit Vectors. 2018;11:569.

11. Bobić B, Thomas LF, Djurković OD, Devleesschauwer B, Dermauw $V$, Dorny P, et al. Epidemiology of Taenia saginata taeniosis/cysticercosis in the Russian Federation. Parasit Vectors. 2018;11:636.

12. Saratsis A, Sotiraki S, Braae UC, Devleesschauwer B, Dermauw V, Eichenberger RM, et al. Epidemiology of Taenia saginata taeniosis/cysticercosis: a systematic review of the distribution in the Middle East and North Africa. Parasit Vectors. 2019;12:113.

13. Braae $U C$, Thomas LF, Robertson LJ, Dermauw V, Dorny P, Willingham AL, et al. Epidemiology of Taenia saginata taeniosis/cysticercosis: a systematic review of the distribution in the Americas. Parasit Vectors. 2018;11:518.

14. Dermauw V, Dorny P, Braae UC, Devleesschauwer B, Robertson LJ, Saratsis A, et al. Epidemiology of Taenia saginata taeniosis/cysticercosis: a systematic review of the distribution in the southern and eastern Africa. Parasit Vectors. 2018;11:578. 
15. OIE Handistatus II. Office International des Epizooties, Paris. 2018. http://web.oie.int/hs2/report.asp. Accessed 8 Apr 2019.

16. OIE World Animal Health Information Database (WAHIS). Office International des Epizooties, Paris. 2018. http://www.oie.int/wahis_2/public/ wahid.php/Wahidhome/Home. Accessed 8 Apr 2019.

17. Auta T, Reuben WJ, Abdulhadi JB, Mohammed JA. A comparative study on the prevalence of intestinal helminthes among rural and sub-urban pupils in Gwagwada, Nigeria. J Parasitol Vector Biol. 2014;5:87-91.

18. Akinbo FO, Okaka CE, Omoregie R. Prevalence of intestinal parasitic infections among HIV patients in Benin City, Nigeria. Libyan J Med. 2010;5:5506.

19. Auta T, Kogi E, Kokori AuduO. Studies on the intestinal helminths infestation among primary school children in Gwagwada, Kaduna, North Western Nigeria. J Biol Agric Healthc. 2013;3:48-54.

20. Adeniran AA, Mogaji HO, Aladesida AA, Olayiwola IO, Oluwole AS, Abe EM, et al. Schistosomiasis, intestinal helminthiasis and nutritional status among preschool-aged children in sub-urban communities of Abeokuta, Southwest, Nigeria. BMC Res Notes. 2017;10:637.

21. Adoke K, Iliyasu Y, Adoke A, Ahmed S. Neglected tropical diseases: A histopathological review. Virchows Arch. 2017;471:S30.

22. Ademowo GO, Rabiu O, Kosoko A, Dada-adegbola H, Arinola G, Falade C. Prevalence and interaction of malaria and helminth co-infections among symptomatic and asymptomatic children in Southwest Nigeria. Int J Infect Dis. 2014;21:297.

23. Ekong PS, Juryit R, Dika NM, Nguku P, Musenero M. Prevalence and risk factors for zoonotic helminth infection among humans and animalsJos, Nigeria, 2005-2009. Pan Afr Med J. 2012;12:2005-9.

24. Secka A, Grimm F, Marcotty T, Geysen D, Niang AM, Ngale V, et al. Old focus of cysticercosis in a senegalese village revisited after half a century. Acta Trop. 2011;119:199-202.

25. Chirdan L, Yusufu L, Ameh E, Shehu S. Meckel's diverticulitis due to Taenia saginata: a case report. East Afr Med J. 2001;78:107-8.

26. Lopez-Caleya JF, Contreras SN, Martin-Rodrigo L. Taenia saginata: an imported case. Rev Esp Enferm Dig. 2015;107:440-1.

27. Ogunrinade A, Oyekole O. Evaluation of the efficiency of beef inspection procedures for tuberculosis, fascioliasis and cysticercosis in a Nigerian abattoir. Prev Vet Med. 1990;8:71-5.

28. Opara MN, Ukpong UM, Okoli IC, Anosike JC. Cysticercosis of slaughter cattle in southeastern Nigeria. Ann N Y Acad Sci. 2006;1081:339-46.

29. Jacob J, Ashkenazi M. The world cookbook: the greatest recipes from around the globe. Santa Barbara: Greenwood; 2014.

30. Massaquoi R. Foods of Sierra Leone and other West African countries, a cookbook and food-related stories. Bloomington: Authorhouse; 2011.

31. Madinga J, Kanobana K, Lukanu P, Abatih E, Baloji S, Linsuke S, et al. Geospatial and age-related patterns of Taenia solium taeniasis in the rural health zone of Kimpese, Democratic Republic of Congo. Acta Trop. 2016;165:100-9.

32. Gweba M, Faleke OO, Junaidu A, Fabiyi JP, Fajinmi AO. Some risk factors for Taenia solium cysticercosis in semi-intensively raised pigs in Zuru, Nigeria. Vet Ital. 2010;46:57-67.

33. Dermauw V, Carabin H, Ganaba R, Cissé A, Tarnagda Z, Gabriël S, et al. Factors associated with the 18-month cumulative incidence of seroconversion of active infection with Taenia solium cysticercosis: a cohort study among residents of 60 villages in Burkina Faso. Am J Trop Med Hyg. 2018;99:1018-27.

34. Permin A, Yelifari L, Bloch P, Steenhard N, Hansen NP, Nansen P. Parasites in cross-bred pigs in the Upper East Region of Ghana. Vet Parasitol. 1999;87:63-71.

35. Vondou L, Zoli AP, Nguekam, Pouedet S, Assana E, Kamga Tokam AC, et al. La taeniose/cysticercose à Taenia solium dans la Menoua (Ouest-Cameroun). Parasite. 2002;9:271-4.

36. Braae UC, Saarnak CFL, Mukaratirwa S, Devleesschauwer B, Magnussen P, Johansen MV. Taenia solium taeniosis/cysticercosis and the co-distribution with schistosomiasis in Africa. Parasit Vectors. 2015;8:323.

37. Laranjo-González M, Devleesschauwer B, Gabriël S, Dorny P, Allepuz A. Epidemiology, impact and control of bovine cysticercosis in Europe: a systematic review. Parasit Vectors. 2016;9:81.

38. Eichenberger RM, Lewis F, Gabriël S, Dorny P, Torgerson PR, Deplazes P. Multi-test analysis and model-based estimation of the prevalence of Taenia saginata cysticercus infection in naturally infected dairy cows in the absence of a "gold standard" reference test. Int J Parasitol. 2013;43:853-9.
39. Ouedraogo A, Tiono A, Amidou D, Ouedraogo A, Ouedraogo E, Kabore Y, et al. Site characterization for a malaria vaccine trial in the Saponé health district in Burkina Faso: seasonal prevalence of main parasites infestation. Am J Trop Med Hyg. 2010;83:48.

40. Nkenfou CN, Nana CT, Payne VK. Intestinal parasitic infections in HIV infected and non-infected patients in a low HIV prevalence region, WestCameroon. PLoS ONE. 2013:8:e57914.

41. Ajeagah G, Wouafo M, Ezenguele G, Nzukam J. Presence of gastrointestinal parasites in a tropical urban region (Yaoundé, Cameroon). Comp Parasitol. 2013;80:279-83.

42. Kyambikwa Bisangamo C, Jabari Mutwa P, Mulongo Mbarambara P. Profil des parasitoses intestinales chez les enfants d'âge scolaire de Kiliba (est de la RD Congo). Med Sante Trop. 2017;27:209-13.

43. Gyorkos TW, Camara B, Kokoskin E, Carabin H, Prouty R. Enquëte de prévalence parasitaire chez les enfants d'âge scolaire en Guinée (1995). Sante. 1996;6:377-81.

44. Egwunyenga AO, Ajayi JA, Nmorsi OPG, Duhlinska-Popova DD. Plasmoduim/intestinal helminth co-infections among pregnant Nigerian women. Mem Inst Oswaldo Cruz. 2001;96:1055-9.

45. Anyaeze CM. Reducing burden of hookworm disease in the management of upper abdominal pain in the tropics. Trop Doct. 2003;33:174-5.

46. Kamalu N, Uwakwe F, Opara J. Prevalence of intestinal parasite among high school students in Nigeria. Acad J Interdiscip Stud. 2013;2:9-16.

47. Okeniyi JAO, Ogunlesi TA, Oyelami OA, Adeyemi LA. Effectiveness of dried carica papaya seeds against human intestinal parasitosis: a pilot study. J Med Food. 2007;10:194-6.

48. Ekpo UF, Odoemene SN, Mafiana CF, Sam-Wobo SO. Helminthiasis and hygiene conditions of schools in Ikenne, Ogun State, Nigeria. PLoS Negl Trop Dis. 2008:2:e146.

49. Ugbomoiko US, Ofoezie IE. Multiple infection diagnosis of intestinal helminthiasis in the assessment of health and environmental effect of development projects in Nigeria. J Helminthol. 2007;81:227-31.

50. Agbolade OM, Agu NC, Adesanya OO, Odejayi AO, Adigun AA, Adesanlu $\mathrm{EB}$, et al. Intestinal helminthiases and schistosomiasis among school children in an urban center and some rural communities in southwest Nigeria. Korean J Parasitol. 2007;45:233.

51. Abaver DT, Nwobegahay JM, Goon DT, Iweriebor BC, Anye DN. Prevalence of intestinal parasitic infections among HIV/AIDS patients from two health institutions in Abuja, Nigeria. Afr Health Sci. 2011;11:S24-7.

52. Abelau M, Goselle O, Udeh E, D-Popova D, Popov T. A comparative study of the prevalence of helminth parasites in HIV seropositive and HIV seronegative individuals in plateau state. Niger Ann Nat Sci. 2011;11:22-32.

53. Damen JG, Lar P, Mershak P, Mbaawuga EM, Nyary BW. A comparative study on the prevalence of intestinal helminthes in dewormed and nondewormed students in a rural area of North-Central Nigeria. Lab Med. 2010;41:585-9

54. Ejima L, Ajogun R. The prevalence and health implications of the ova of human intestinal helminth parasites isolated from faeces collected near students' hostels, federal polytechnic, Idah, Kogi State, Nigeria. Int J Trop Med. 2011;6:15-8.

55. Banjo T, Amoo A, Busari A, Kama A, Lawal I, Ogundahunsi O, et al. Intestinal parasites among abattoir workers in Abeokuta. Am J Res Commun. 2013;1:84-96.

56. Shehu M, Kabiru A, Abubakar U, Muhammad K. prevalence of intestinal helminth infections among school children in relation to occupation of parents and toilets facilities in Maru LGA Zamfara State. J Biol Agric Healthc. 2013:3:87-91.

57. Abah AE, Arene FOI. Status of intestinal parasitic infections among primary school children in Rivers State, Nigeria. J Parasitol Res. 2015;2015:937096.

58. Nwalorzie C, Onyenakazi S, Ogwu S, Okafor A. Predictors of intestinal helminthic infections among school children in Gwagwalada, Abuja, Nigeria. Niger J Med J Natl Assoc Resid Dr Niger. 2015;24:233-41.

59. Omalu ICJ, Paul S, Adeniran LA, Hassan SC, Pam VA, Eke SS, et al. Assessment of the level of gastrointestinal parasites infection among food vendors in Minna, North central Nigeria. Annu Rev Res Biol. 2013;3:705-13.

60. Adekolujo DR, Olayinka SO, Adeniji JA, Oyeyemi OT, Odaibo AB. Poliovirus and other enteroviruses in children infected with intestinal parasites in Nigeria. J Infect Dev Ctries. 2015;9:1166-71.

61. Taiwo OT, Sam-Wobo SO, Idowu OA, Talabi AO, Taiwo AM. Comparative assessment of intestinal helminths prevalence in Water, Sanitation and 
Hygiene (WASH) intervention and non-intervention communities in Abeokuta, Nigeria. Asian Pac J Trop Biomed. 2017;7:524-32.

62. Amuta E, Houmsou R, Mker S. Knowledge and risk factors of intestinal parasitic infections among women in Makurdi, Benue State. Asian Pac J Trop Med. 2010;3:993-6.

63. Dangana A, Abayomi R, Way G, Akobi O. Survey of Ascaris lumbricoides among pupils of primary school in Jos south local government area of Plateau State, Nigeria. Afr J Microbiol Res. 2011;5:2524-7.

64. Ojurongbe O, Raji OA, Akindele AA, Kareem MI, Adefioye OA, Adeyeba AO. Cryptosporidium and other enteric parasitic infections in HIV-seropositive individuals with and without diarrhoea in Osogbo, Nigeria. Br J Biomed Sci. 2011;68:75-8.

65. Ifeadike C, Ironkwe O, Adogu POU, Nnebue C, Emelumadu O, Nwabueze $\mathrm{S}$, et al. Prevalence and pattern of bacteria and intestinal parasites among food handlers in the Federal Capital Territory of Nigeria. Niger Med J. 2012;53:166-71.

66. Enimien OJ, Fana SA, Emmanuel WB. Intestinal helminthic infection in Numan (Northeast Nigeria). Int J Progress Sci Technol. 2015;1:1-4

67. Ojurongbe O, Oyesiji K, Ojo J, Odewale G, Adefioye O, Olowe A, et al. Soil transmitted helminth infections among primary school children in Ile-Ife Southwest, Nigeria: a cross-sectional study. Int Res J Med Med Sci. 2014;2:6-10.

68. Thomas H, Jatau E, Inabo H, Garba D. Prevalence of intestinal helminths among primary school children in Chikun and Kaduna South Local Government areas of Kaduna state, Nigeria. J Med Med Res. 2014;2:6-11.
69. Umeh C, Mbanugo J, Ezeugoigwe N. Prevalence of intestinal helminthes parasite in stools of nursery and primary schools pupils in Uga, Anambra State, Nigeria. Sky J Microbiol Res. 2015;3:6-10.

70. Diouf S, Diallo A, Camara B, Diagne I, Ndiaye O, Tall A, et al. Etat vaccinal et pathologies de l'enfant en zone rurale Senegalaise (Khombole). Arch Pediatr. 1999;6:903.

71. Ndiaye D, Ndiaye M, Gueye PAL, Badiane A, Fall ID, Ndiaye YD, et al. Prévalence des helminthoses digestives diagnostiqués à l'hôpital Le Dantec de Dakar, Sénégal. Med Sante Trop. 2013;23:35-8.

72. Chartier C, Bushu M, Kamwenga D. Les dominantes du parasitisme helminthique chez les bovins en Ituri (Haut-Zaïre). III. Répartition géographique et prévalence des principaux helminthes. Rev Elev Med Vet Pays Trop. 1991:44:61-8.

73. Cadmus SIB, Adesokan HK. Causes and implications of bovine organs/ offal condemnations in some abattoirs in western Nigeria. Trop Anim Health Prod. 2009:41:1455-63.

\section{Publisher's Note}

Springer Nature remains neutral with regard to jurisdictional claims in published maps and institutional affiliations.
Ready to submit your research? Choose BMC and benefit from:

- fast, convenient online submission

- thorough peer review by experienced researchers in your field

- rapid publication on acceptance

- support for research data, including large and complex data types

- gold Open Access which fosters wider collaboration and increased citations

- maximum visibility for your research: over 100M website views per year

At BMC, research is always in progress.

Learn more biomedcentral.com/submissions 